\section{Vacation School on Social Biology}

A vacation school on "Social Biology in Relation to Human Life and Culture" is to be held under the auspices of the British Social Hygiene Council, beginning on July 30 at Eton College. The school will last for a fortnight; the cost will be $£ 6$ 6s. a week inclusive. The programme will consist of morning instructional courses on social biology, its place in education and its bearing on current social problems. For these, Prof. A. E. Heath, professor of philosophy in University College, Swansea, Dr. Marjory Gibbons, Mrs. E. J. Hatfield, Prof. L. P. W. Renouf, professor of zoology in University College, Cork, $\mathbf{M r}$. $\mathbf{R}$. Weatherall (of Eton College) and others are making themselves responsible. Still wider aspects of social biology will be dealt with in evening lectures and conferences, in which Prof. F. A. E. Crew, Mr. W. L. Sumner, and Father Leycester King are hoping to participate. In the first week the courses will be planned to appeal mainly to teachers of all kinds, not only to science teachers. In the second week they will relate to problems which concern not only educationists but also welfare workers, magistrates, labour managers and all others confronted with present-day social and administrative problems. Further information can be obtained from the British Social Hygiene Council, Tavistock House South, Tavistock Square, London, W.C.1.

\section{The Ray Society}

AT the general meeting of the Ray Society held on March 25, it was agreed that, under suspension of the laws of the Society, the officers and Council at present serving be re-elected for the current year. In the annual report of the Council it was stated that the affairs of the Society continue in a satisfactory condition. Prof. Tattersall's monograph on the "British Mysidacea" is approaching completion and a considerable number of the illustrations are in the hands of the engravers. Proposals for the publication of several other works are under consideration by the Council, but under present conditions considerable delay in publication is unavoidable.

\section{Science and the War Effort in the United States}

A PAPER on "The Fuller Utilisation of Scientific Resources for Total War" presented by Dr. T. Rosebury at a meeting of the New York Branch of the American Association of Scientific. Workers on October 7, which has now, appeared in Science (96, 571 ; December 25, 1942), shows a similar concern over the failure to utilize scientific resources to that which exists in Great Britain, and also that the American Association of Scientific Workers is actively concerned with this problem. The broad outlines do not of course differ in the two countries, and with much that is being done in the United States readers of NATURE are already familiar. The chief feature of interest in Dr. Rosebury's paper is its account of the encouragement and organization of individual volunteer scientific activity by the Office of Scientific Research and Development. Emphasizing that leadership however competent is not enough, Dr. Rosebury points out that any responsible scientific worker can formulate a war project and submit it us an application for a contract to the O.S.R.D. or to one of its sub-committees. If the application is approved, a contract is granted, and funds for assisting personnel and for equipment and supplies are made available for the work; Dr. Rosebury describes the way in which the services of a group of bacteriologists in New York were utilized in this way. Finally, he indicates the way in which scientific workers can assist on the home front, and deal with the problems that will result from shortages of trained personnel and assist in securing the full utilization of scientific facilities, equipment and materials, where the National Registry of Rare Chemicals, maintained under the auspices of the Armour Fomsuaulon, and the National Research Council have already pointed the way. Dr. Rosebury, however, suggests that ultimately all scientific activity should be centralized and co-ordinated by a single government agency.

\section{Sterilization of Sulphanilamide Powder}

THE report of a fatal case of tetanus due possibly to infection from the container of a sulphonamide powder applied locally emphasizes the desirability of the practice, already adopted in the United States, by which all sulphonamide preparations intended for topical application are marketed ready sterilized in sterilized containers. At a conference recently held between representatives of the Medical Research Council and of the Association of British Chemical Manufacturers, it was agreed that the Hynson, Westcott and Dunning procedure is suitable for adoption also by British manufacturers of sulphanilamide powder, and that the powder thus sterilized should be issued in sterile packets each containing $5 \mathrm{gm}$. Since this recommendation must inevitably take some time to put into full effect and would not apply to existing stocks of the powder held at hospitals and first-aid posts, suitable methods for small-scale sterilization were also considered and various procedures recommended. It is thought that sulphanilamide powder for local application should not cake or be more than slightly discoloured by any of the proposed techniques.

\section{Announcements}

ThE Association of University Professors and Lecturers of the Allied Countries in Great Britain has arranged a conference, to be held at the Royal Institution on April 10. The morning session, beginning at 10 a.m., will deal with "The Function of a University in a Modern Community" ; the after. noon session, beginning at 2.30 p.m., with "Methods of Practical Co-operation between Allied Universities in the Future". Tickets can be obtained from the Conference Secretary, Association of University Professors, 40 Queen's Gate, S.W.7.

The Ministry of Agriculture and Fisheries invites applications for ten senior scholarships, tenable at agricultural colleges or university departments of agriculture, for diploma or degree courses in an agricultural subject or at veterinary colleges for courses in veterinary science; and six extended junior scholarships (for those who have already held junior awards), and thirty junior scholarships, tenable at farm institutes or similar institutions, for courses not exceeding a year in duration, in agriculture, horticulture, or dairying. Information concerning the scheme and forms of application may be obtained from the Secretary of the Ministry, Block 4, Bickenhall Mansions, Baker Street, London, W.I, or from the offices of County Councils. The latest date for submitting applications is April 30. 